\title{
THE VARIABILITY OF NON-HEMOGLOBIN IRON ${ }^{1}$
}

\author{
BY THEODORE G. KLUMPP \\ (From the Department of Internal Medicine of Yale University School of Medicine \\ and the Medical Service of the New Haven Hospital, New Haven)
}

(Received for publication December 22, 1934)

In this paper data on the range of variation of non-hemoglobin iron in human blood will be presented. The significance of these variations in relation to (a) the calculation of hemoglobin, or oxygen capacity from the determinations of total blood iron, and reciprocally, (b) the deduction of values for total blood iron from determinations of hemoglobin or oxygen capacity, will be considered.

Because of the difficulties inherent in the direct determination of hemoglobin there has been a widespread interest in the indirect methods of approach. Of these the oxygen capacity is the most accurate, but there has been an idea in the minds of many that it is a formidable procedure and, as an alternative, there has been a growing tendency to arrive at values for hemoglobin by measurements of total blood iron. Wong (1), Fowweather (2), Sackett (3), Dupray (4), and others have calculated hemoglobin values from determinations of total blood iron. Kennedy (5) believes that total blood iron can be correlated with oxygen capacity and hemoglobin content as determined by colorimetric methods. Murphy, Lynch and Howard (6) have proposed a new index, the "iron index," obtained by dividing the milligrams of iron in $100 \mathrm{cc}$. of blood by the number of red blood cells in the same volume, as an expression of the concentration of iron in the red blood cells. The validity of these values rests on the assumption that all the iron of the blood is contained within the red blood cells, or combined with hemoglobin, and behaves as a single variable.

In 1898 Abderhalden (7) first showed that there was more iron in the blood of various animals than could be attributed to the hemoglobin alone. He found that the non-hemoglobin iron amounted to 10 per cent of the total blood iron in the ox, 3.6 per cent in the horse, and 6 per cent in the rabbit. Since then Ehrlich and Lazarus (8), Rosin and Jellinek (9), Erben (10), Seiller

1 Aided by a grant from the research fund of the Yale School of Medicine.
(11), Lintzel (12), Freund (13), Barkan (14), Brugsch (15), Warburg and Krebs (16), Langer (17), Locke, Main and Rosbash (18), Dominici (19), McIntosh (20) and many others have verified the presence of non-hemoglobin iron in human blood. The values have varied from minute amounts to 10 per cent of the total blood iron. Barkan (14) showed that there was no relation between the level of hemoglobin and non-hemoglobin iron among twenty-one different individuals nor in the same person under varying conditions. Riecker and Winters (21) found no direct relationship between serum iron and the level of hemoglobin in dogs. Schultze and Elvehjem (22) could obtain no agreement between total blood iron and hemoglobin in fowl.

Because of the fundamental importance of this question to the problems of iron metabolism, iron transport, and the relations between iron and hemoglobin, it seemed desirable to study the magnitude and the variations of non-hemoglobin iron in human beings. With this in mind seventytwo determinations of total blood iron and oxygen capacity were made on the blood of fifty-seven individuals. Patients with a wide variety of disease conditions, as well as normals, were included, in order that the results might give, as far as possible, a picture of the range of both physiologic and pathologic variations. From the work of Barkan $(14,23)$ who showed that all but a small fraction of the non-hemoglobin iron was contained within the red blood cells, it is obvious that valid figures for non-hemoglobin iron cannot be derived from analyses of blood serum or plasma. Since one gram-molecule of hemoglobin combines with one gram-molecule of iron and one of oxygen, values for hemoglobin-iron can be calculated from measurements of blood oxygen capacity, with the high degree of accuracy inherent in this procedure. To obtain the value for hemoglobin iron the figure for oxygen capacity is multiplied by the factor 2.495. By subtracting this value from the total blood iron determined by analysis, a figure for 
TABLE I

Outline of experimental data

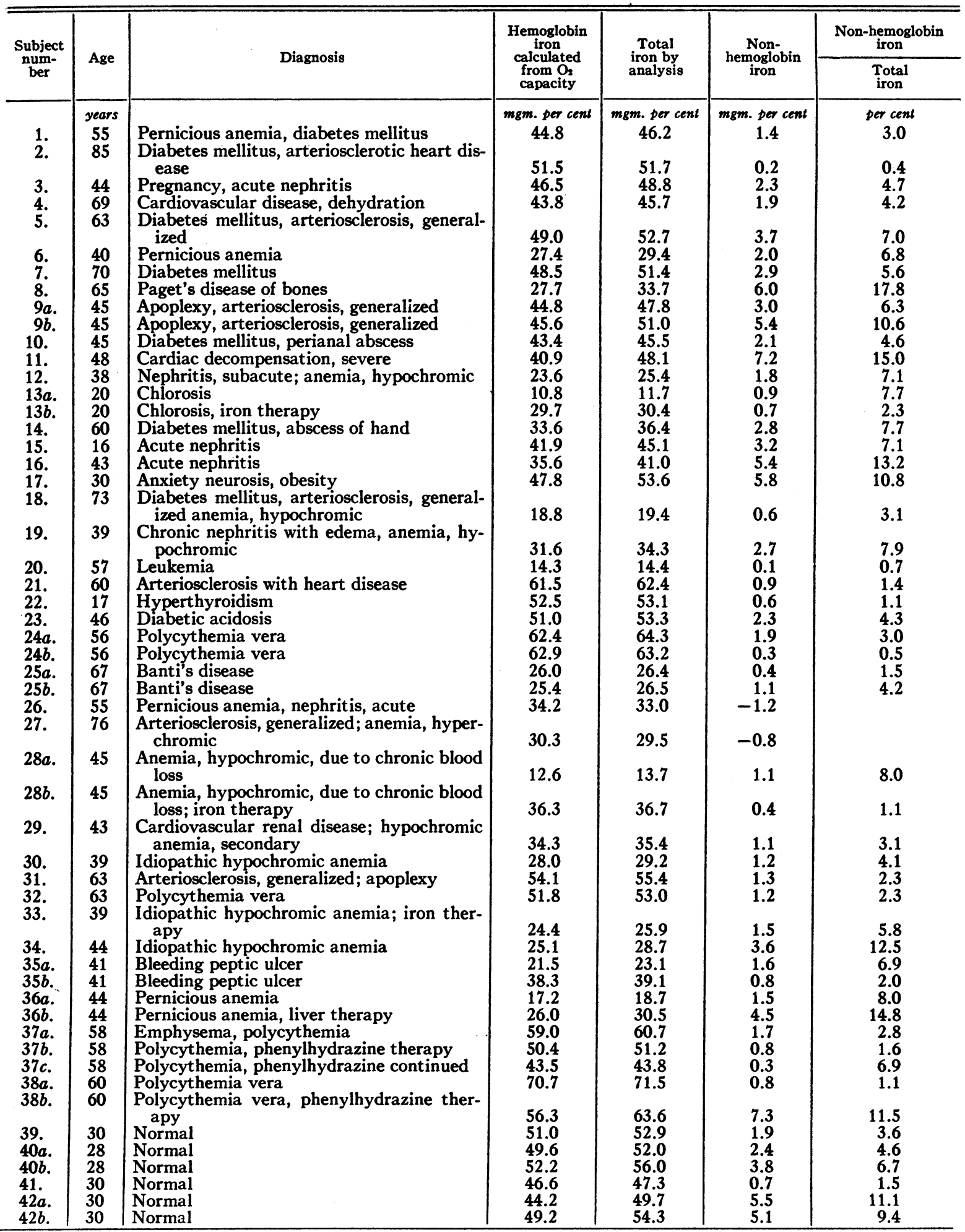


TABLE I (continued)

\begin{tabular}{|c|c|c|c|c|c|c|}
\hline \multirow{2}{*}{$\begin{array}{c}\text { Subject } \\
\text { num- } \\
\text { ber }\end{array}$} & \multirow{2}{*}{ Age } & \multirow{2}{*}{ Diagnosis } & \multirow{2}{*}{$\begin{array}{c}\text { Hemoglobin } \\
\text { iron } \\
\text { calculated } \\
\text { from } \mathrm{O}_{2} \\
\text { capacity }\end{array}$} & \multirow{2}{*}{$\begin{array}{c}\text { Total } \\
\text { iron by } \\
\text { analysis }\end{array}$} & \multirow{2}{*}{$\begin{array}{c}\text { Non- } \\
\text { hemoglobin } \\
\text { iron }\end{array}$} & $\begin{array}{c}\text { Non-hemoglobin } \\
\text { iron }\end{array}$ \\
\hline & & & & & & $\begin{array}{l}\text { Total } \\
\text { iron }\end{array}$ \\
\hline $\begin{array}{l}42 c . \\
43 a . \\
43 b . \\
44 . \\
45 a . \\
45 b . \\
46 . \\
47 . \\
48 . \\
49 . \\
50 . \\
51 . \\
52 . \\
53 . \\
54 . \\
55 . \\
56 . \\
* 57 .\end{array}$ & $\begin{array}{l}\text { years } \\
30 \\
31 \\
31 \\
35 \\
25 \\
25 \\
21 \\
25 \\
25 \\
26 \\
26 \\
21 \\
38 \\
26 \\
21 \\
22 \\
28 \\
25\end{array}$ & $\begin{array}{l}\text { Normal } \\
\text { Normal } \\
\text { Normal } \\
\text { Normal } \\
\text { Normal } \\
\text { Normal } \\
\text { Normal } \\
\text { Normal } \\
\text { Normal } \\
\text { Normal } \\
\text { Normal } \\
\text { Normal } \\
\text { Normal } \\
\text { Normal } \\
\text { Normal } \\
\text { Normal } \\
\text { Normal } \\
\text { Normal }\end{array}$ & $\begin{array}{c}\text { mgm. per cent } \\
47.8 \\
50.2 \\
47.3 \\
48.3 \\
45.4 \\
49.1 \\
44.2 \\
54.7 \\
51.1 \\
48.8 \\
47.2 \\
52.8 \\
57.4 \\
45.7 \\
42.2 \\
45.1 \\
45.2 \\
54.2\end{array}$ & $\begin{array}{c}\text { mgm. per cent } \\
50.4 \\
52.7 \\
49.2 \\
50.7 \\
48.5 \\
49.1 \\
46.8 \\
58.6 \\
54.7 \\
51.4 \\
48.3 \\
57.0 \\
60.2 \\
46.3 \\
43.3 \\
47.1 \\
45.9 \\
69.5\end{array}$ & $\begin{array}{c}\text { mgm. per cent } \\
2.6 \\
2.5 \\
1.9 \\
2.4 \\
3.1 \\
0.0 \\
2.6 \\
3.9 \\
3.6 \\
2.6 \\
1.1 \\
4.2 \\
2.8 \\
0.6 \\
1.1 \\
2.0 \\
0.7 \\
15.3\end{array}$ & $\begin{array}{c}\text { per cent } \\
5.2 \\
4.7 \\
3.9 \\
4.7 \\
6.4 \\
0.0 \\
5.6 \\
6.7 \\
6.6 \\
5.1 \\
2.3 \\
7.4 \\
4.7 \\
1.3 \\
2.5 \\
4.2 \\
1.5 \\
22.0\end{array}$ \\
\hline
\end{tabular}

\begin{tabular}{l|c|l}
\hline Mean non-hemoglobin iron & $2.2 \mathrm{mgm}$. per cent & $\begin{array}{l}\text { Standard deviation } \pm 1.74 \mathrm{mgm} . \\
\text { per cent }\end{array}$ \\
\hline $\begin{array}{l}\text { Non-hemoglobin iron } \\
\text { Total iron }\end{array}$ & 5.3 per cent & $\begin{array}{l}\text { Standard deviation } \pm 3.9 \mathrm{per} \\
\text { cent }\end{array}$ \\
\hline $\begin{array}{l}\text { Mean error of duplicate determinations of total iron } \\
\begin{array}{l}\text { Mean error of duplicate determinations of oxygen capacity in } \\
\text { terms of hemoglobin iron }\end{array}\end{array}$ & $0.38 \mathrm{mgm}$. per cent & $\begin{array}{l}\text { Standard deviation } \pm 0.46 \mathrm{mgm} . \\
\text { per cent }\end{array}$ \\
\hline
\end{tabular}

*Omitted from statistical consideration.

true non-hemoglobin iron can be obtained. Barkan (24) attempted to arrive at values for nonhemoglobin iron by ultrafiltration of hemolyzed blood, and Winegarden and Borsook (25) by dialysis; but in view of the unstable nature of hemoglobin when subjected to manipulation, these methods cannot be considered reliable.

Oxygen capacity was determined in duplicate by the carbon monoxide method of Van Slyke and Hiller as described by Peters and Van Slyke (26). Total blood iron was measured in duplicate or triplicate by volumetric titration with titanium according to the technique recently described (27). Data concerning the sensitivity of this method as well as recovery experiments are given in that paper.

\section{RESULTS}

The experimental findings are presented in Table I.
The value for non-hemoglobin iron of Case 57 was omitted in the mathematical treatment of results because it lies so far beyond the range of the other findings that it is highly probable that some gross technical error was undetected.

In this series an average of 5.3 per cent of the total iron was found uncombined with active hemoglobin. This is in close agreement with the work of Barkan (24) who reports that the free iron of the blood amounts to from 5 to 6 per cent of the hemoglobin iron. In Figure 1 the values for non-hemoglobin iron are plotted against oxygen capacities. It can be readily seen that there is no correlation between non-hemoglobin iron and oxygen capacity. These results indicate that attempts to arrive at values for hemoglobin by determination of total blood iron or vice versa, are subject to an average error of 5.3 per cent with a standard deviation of 3.9 per 
cent, and a possible error as great as $\mathbf{1 7 . 8}$ per cent. The scatter of the actual values of non-hemoglobin iron is given in Figure 2. The wide range of variations of non-hemoglobin iron is apparent.

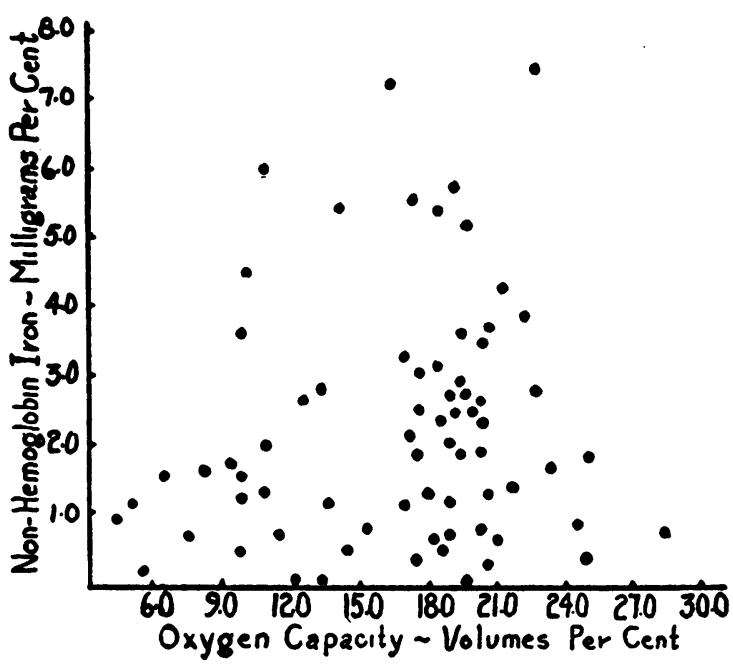

Fig. 1. Correlation Chart.

The relation between non-hemoglobin iron and oxygen capacity.

In agreement with Barkan (23), it was evident from simultaneous determinations of total blood iron, oxygen capacity, and serum iron, that the serum contained only a fraction of the non-hemoglobin iron. This will be considered in detail in another report.

\section{SUM MARY}

From determinations of oxygen capacity and total blood iron in fifty-seven subjects under various conditions, values for non-hemoglobin iron were obtained. It was found that non-hemo- globin iron varies widely and is a significant fraction of total iron. For these reasons, attempts to correlate values for hemoglobin and oxygen capacity with determinations of total blood iron are fruitless.

The generous assistance of Dr. Anna J. Eisenman is appreciatively acknowledged.

\section{BIBLIOGRAPHY}

1. Wong, S. Y., Colorimetric determination of iron and hemoglobin in blood. II. J. Biol. Chem., 1928, 77, 409.

2. Fowweather, F. S., The determination of iron in blood, tissues, and urine. Biochem. J., 1926, 20, 93.

3. Sackett, G. E., Hemoglobin and iron in blood. J. Lab. and Clin. Med., 1925, 10, 1018.

4. Dupray, M., A colorimetric method for the determination of iron and hemoglobin in the blood. J. Lab. and Clin. Med., 1927, 12, 917.

5. Kennedy, R. P., The quantitative determination of iron in tissues. J. Biol. Chem., 1927, 74, 385.

6. Murphy, W. P., Lynch, R., and Howard, I. M., The value of determinations of the iron content of whole blood. Arch Int. Med., 1931, 47, 883.

7. Abderhalden, E., Zur quantitativen vergleichenden Analyse des Blutes. Ztschr. f. physiol. Chem., 1898, 25, 65.

8. Ehrlich, P., and Lazarus, A., Die Anaemie. Nothnagel's Handb. spec. Path. u. Therap., Alfred Hölder, Wien, 1898, 8, 11.

9. Rosin, H., and Jellinek, S., Ueber Färbekraft und Eisengehalt des menschlichen Blutes. Ztschr. f. Klin. med., 1900, 39, 109.

10. Erben, F., Die Chemische Zusammensetzung des Blutes bei perniciöser Anämie. Ztschr. f. Klin. med., 1900, 40, 266.

11. Seiller, R. von, Zur Kenntniss eisenhaltiger Substanzen im Blute. Beitr. z. Geburtsh. u. Gynäkol., Rudolf Chrobak, 1, 354, Alfred Hölder, Wien, 1903.

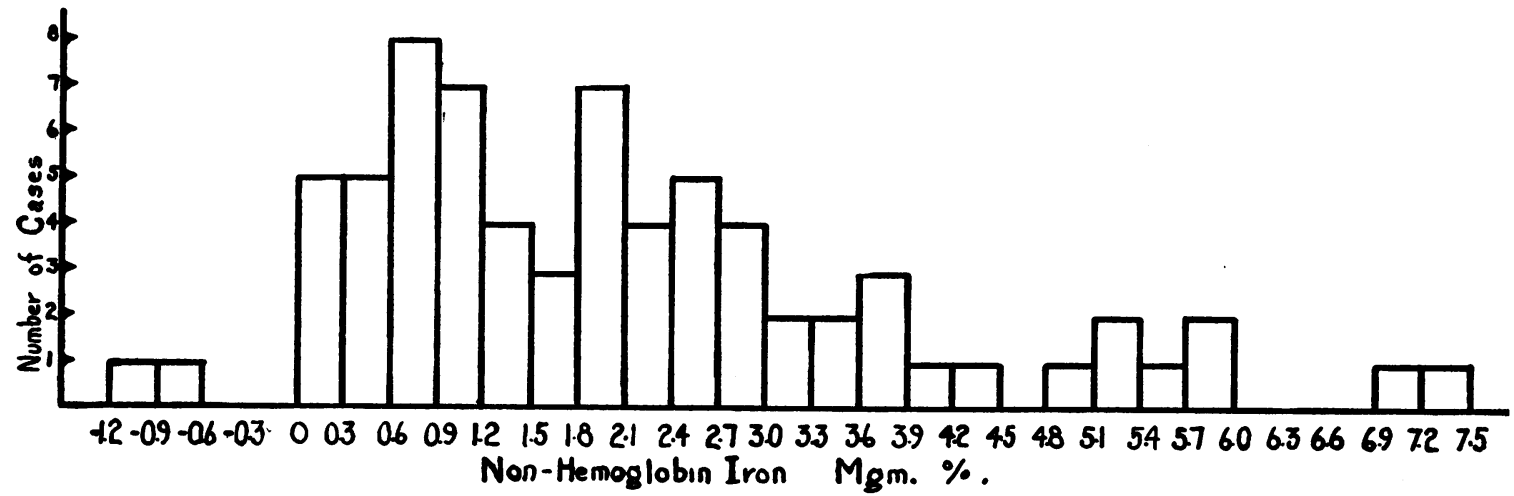

Fig. 2. The Distribution of Values for Non-Hemoglobin Iron. 
12. Lintzel, W., Zur frage des Eisenstoff wechsels. I. Das Verhalten des Blutfarbstoffes bei künstlicher Verdauung. Ztschr. f. Biol., 1925, 83, 289.

13. Freund, E., Ueber einen neuen eisenhaltigen Blutfarbstoff. Wien Klin. Wchnschr., 1903, 16, 808.

14. Barkan, G., Eisenstudien. II. Über das leicht abspaltbare Bluteisen und sein Verhältnis zum Hämoglobin. Ztschr. f. physiol. Chem., 1927, 171, 179.

15. Brugsch, T., Lebererkrankungen mit Ikterus und Eisenstoff wechsel. Med. Klin., 1931, 27, 536.

16. Warburg, O., and Krebs, H. A., Uber locker gebundenes Kupfer und Eisen im Blutserum. Biochem. Ztschr., 1927, 190, 143.

17. Langer, A., Über den Gehalt an Ferrieisen in normalen und pathologischen Seren. Biochem. Ztschr., 1931, 242, 316.

18. Locke, A., Main, E. R., and Rosbash, D. O., The copper and non-hemoglobinous iron contents of the blood serum in disease. J. Clin. Invest., 1932, 11, 527.

19. Dominici, G., Ricerche sull'esistenza nel sangue di un ferro non emoglobinico. Gior. d. r. Accad. di med. di Torino, 1929, 92, 216.
20. McIntosh, J. F., The nonprotein iron of the blood. J. Clin. Invest., (Proc. Am. Soc. Clin. Invest.), 1933, $12,967$.

21. Riecker, H. H., and Winters, M. E., Serum iron determinations applied to the study of experimental anemia. Am. J. Physiol., 1930, 92, 196.

22. Schultze, M. O., and Elvehjem, C. A., An improved method for the determination of hemoglobin in chicken blood. J. Biol. Chem., 1934, 105, 253.

23. Barkan, G., Über Säurelösliches Eisen im Blutserum. Klin. Wchnschr., 1927, 6, 1615.

24. Barkan, G., Eisenstudien. I. Zur frage der Einwirkung von Verdauungsfermenten auf das Hämoglobineisen. Ztschr. f. physiol. Chem., 1925, 148, 124.

25. Winegarden, H. M., and Borsook, H., On the spectrophotometric differentiation of the haemoglobins of different species. J. Cell. and Comp. Physiol, 1933, 3, 437.

26. Peters, J. P., and Van Slyke, D.D., Quantitative Clinical Chemistry. II. Methods. Williams and Wilkins Co., Baltimore, 1932, p. 341.

27. Klumpp, T. G., The determination of iron in biological materials. J. Biol. Chem., 1934, 107, 213. 